\title{
Development of Quasi-static Analysis Program for Catenary Mooring System using OpenFOAM
}

\author{
Jun Hyeok Choi ${ }^{*}$ and Seung Jae Lee* \\ "Division of Naval Architecture and Ocean Systems Engineering, Korea Maritime and Ocean University, Busan, Korea
}

\section{OpenFOAM을 이용한 catenary 계류시스템의 준정적 해석 프로그램 개발}

\author{
최준혁* · 이승재 \\ "한국해양대학교 조선해양시스템공학부
}

KEY WORDS: Hydrodynamics 유체동역학, Mooring system 계류 시스템, Catenary equation 현수선 방정식, Quasi-static 준정적해석, Computational fluid dynamics 전산유체역학, OpenFOAM 오픈폼

\begin{abstract}
Generally, global performance analysis in offshore platforms is performed using potential-based numerical tools, which neglect hydrodynamic viscous effects. In comparison with the potential theory, computational fluid dynamics (CFD) methods can take into account the viscous effects by solving the Navier-Stokes equation using the finite-volume method. The open-source field operation and manipulation (OpenFOAM) C++ libraries are employed for a finite volume method (FVM) numerical analysis. In this study, in order to apply CFD to the global performance analysis of a hull-mooring coupled system, we developed a numerical wave basin to analyze the global performance problem of a floating body with a catenary mooring system under regular wave conditions. The mooring system was modeled using a catenary equation and solved in a quasi-static condition, which excluded the dynamics of the mooring lines such as the inertia and drag effects. To demonstrate the capability of the numerical basin, the global performance of a barge with four mooring lines was simulated under regular wave conditions. The simulation results were compared to the analysis results from a commercial mooring analysis program, Orcaflex. The comparison included the motion of the barge, catenary shape, and tension in the mooring lines. The study found good agreement between the results from the developed CFD-based numerical calculation and commercial software.
\end{abstract}

\section{1. 서 론}

특정 해역에 머무르며 오랜 기간 작업을 수행하는 부유식 해 양구조물의 특성상 정확한 운동응답특성 및 위치유치성능이 요 구된다. 특히 위치 유지 성능은 구조물의 가동률이나 작업능률 에 크게 영향을 미치기 때문에 매우 중요한 요소이다. 본 논문 에서는 파랑 중 해양구조물의 위치를 유지하기 위해 계류 시스 템을 사용하였으며, 그 중에서 현수선 계류(catenary mooring)를 사용하였다.

부유식 해상구조물 및 계류 시스템의 설계 및 성능 검증을 위 해서는 일반적으로 모형실험 및 포텐셜(potential)기반의 수치 기 법을 이용한 연구가 보편적이다. Hong et al.(1988)은 계류된 반 잠수식 시추선의 규칙파 중 운동특성과 현수선 계류선의 인장
력을 실험을 통해 계산하고 이를 3차원 포텐셜 이론의 수치해 석을 통해 비교하였다. Sirnivas et al.(2016)은 부유체와 계류 시 스템의 연성운동에 대해 포텐셜 기반인 프로그램을 개발하고 이를 상용프로그램과 실험을 통해 비교 및 검증하였다.

최근 전산유체역학의 발달로 인해 유체동역학(Hydrodynamic) 분야에서 모형실험의 한계를 보완하고 포텐셜 기반의 수치해석 과 비교하여 보다 정도 높은 해석을 위한 접근이 가능해졌다. Ok et al.(2017)은 오픈소스 CFD 프로그램을 사용하여 파랑 중 단일선체 및 병렬 배치된 두 부유체의 운동에 관해 수치해석을 수행하였다. Wu et al.(2016)은 자체 계류 시스템 모듈을 개발하 고 이를 상용 $\mathrm{CFD}$ 프로그램인 $\mathrm{STAR} \mathrm{CCM}+$ 과 연성을 통한 부 유체와 계류 시스템의 운동특성을 파악하였다.

본 연구에서는 현수선 계류 시스템의 준정적 해석 라이브러리

Received 29 June 2017, revised 4 July 2017, accepted 23 August 2017

Corresponding author Seung Jae Lee : +82-051-410-4309, slee@kmou.ac.kr

It is noted that this paper is revised edition based on proceedings of KAOST 2017 in Busan.

(C) 2017, The Korean Society of Ocean Engineers

This is an open access article distributed under the terms of the creative commons attribution non-commercial license (http://creativecommons.org/licenses/by-nc/3.0) which permits unrestricted non-commercial use, distribution, and reproduction in any medium, provided the original work is properly cited. 
를 개발하고 이를 오픈소스 CFD 프로그램인 Open-source Field Operation And Manipulation(OpenFOAM)과의 연성을 통해 부유체 와 계류 시스템 간의 양방향 연성 모듈을 개발하였다. 여기서 계 류선의 관성과 양력 효과는 고려되지 않았다. 개발된 모듈에 대 한 비교 및 검증을 위해 부유체 운동 계산을 위한 상용프로그램 인 AQWA와 계류선의 장력 계산을 위한 상용프로그램인 Orcaflex를 이용하여 수치해석을 수행하였다. 두 프로그램을 선 택한 이유는 $\mathrm{AQWA}$ 는 포텐셜 기반의 경계요소법을 이용한 파랑 중 부유체의 운동계산 프로그램으로서 유사한 기능을 가진 다른 프로그램에 비해 범용성이 가장 높기 때문이고, Orcaflex는 계류 선의 동적 거동을 계산하는 프로그램 중에 비선형 요소들을 추가 할 수 있는 확장성이 가장 높기 때문에 추후 본 연구의 확장에 대응하기 위함이다.

\section{2. 준정적 해석프로그램의 개발}

\section{1 지배방정식}

본 유동장의 유체는 비압축성·점성유체이며 유동장내의 유동에 대한 속도와 압력을 계산하기 위해 연속방정식과 Navier-Stokes 방 정식을 사용하였다. 각각의 방정식은 식 (1), (2)와 같다.

$$
\begin{aligned}
& \frac{\partial \rho_{m}}{\partial t}+\nabla \cdot\left(\rho_{m} u_{m}\right)=0 \\
& \frac{\partial \rho_{m} u}{\partial t}+\nabla \cdot\left(\rho_{m} u_{m} u_{m}\right)-\mu_{m} \nabla^{2} u_{m}=-\nabla p+\rho g
\end{aligned}
$$

여기서 $u$ 는 유동장의 유체속도, $\rho$ 는 밀도, $t$ 는 시간, $p$ 는 압력, $\mu$ 는 점성계수, $g$ 는 중력가속도, 아래 첨자 $m$ 은 물과 공기로 혼 합된 유체의 물성치를 나타낸다. 유체 간의 구분은 격자 내에 차지하는 체적비율인 $\alpha$ 를 통해 자유수면을 수치적으로 표현하 는 $\mathrm{VOF}$ (Volume of fluid) 기법을 사용하였다. 격자가 물로 완전 히 채워진 경우 $\alpha=1$, 공기로 완전히 채워진 경우 $\alpha=0$, 자유 수면의 체적비율은 $0 \leq \alpha \leq 1$ 로 나타낸다. 두 유체의 밀도와 점 성은 식 (3), (4)와 같다.

$$
\begin{aligned}
& \rho(\alpha)=\rho_{w} \alpha+\rho_{a}(1-\alpha) \\
& \mu(\alpha)=\mu_{w} \alpha+\mu_{a}(1-\alpha)
\end{aligned}
$$

여기서 아래 첨자 $a$ 는 공기 $w$ 는 물을 각각 의미하며 유동장내 에서 유동에 흐름에 따른 자유수면을 계산하기 위한 변수 $\alpha$ 의 변화는 이송방정식인 식 (5)와 같이 정의된다.

$$
\frac{\partial}{\partial t}\left(\alpha \rho_{m}\right)+\nabla \cdot\left(\alpha \rho_{m} u_{m}\right)=0
$$

\subsection{6자유도 운동}

강체로 가정한 부유체의 6 자유도 운동은 다음과 같이 나타낼 수 있다.

$$
\left(F_{C G}\right)_{i}=m \frac{d^{2}\left(x_{C G}\right)_{i}}{d t^{2}}=m \ddot{.}
$$

$$
\left(M_{C G}\right)_{i}=\frac{d}{d t}\left(I_{i j} \frac{d\left(\theta_{C G}\right)_{i}}{d t}\right)=I_{i j} \ddot{\theta_{C G}}
$$

식 (6)은 $x, y, z$ 방향의 병진 운동 방정식이고, 식 (7)은 $x, y, z$ 축에 대한 회전 운동 방정식이다. $m$ 과 $I_{i j}$ 는 각각 부유체의 질 량과 관성모멘트이고 $\ddot{x}$ 와 $\ddot{\theta}$ 는 부유체의 병진, 회전 방향의 가 속도 성분 변화량을 나타낸다. $x_{C G}, \theta_{C G}$ 는 각각 부유체의 병진 운동과 회전운동 변위를 나타내며 $F_{C G}$ 와 $M_{C G}$ 는 각각 부유체 의 무게 중심에 작용하는 병진 운동과 회전운동의 힘과 모멘트 를 나타낸다. 여기서 $F_{C G}$ 와 $M_{C G}$ 는 식 (8), (9)와 같이 세 개의 성분으로 나눌 수 있다.

$$
\begin{aligned}
& F=F_{S}+F_{D}+F_{M} \\
& M=M_{S}+M_{D}+M_{M}
\end{aligned}
$$

병진운동을 기준으로 $F_{S}$ 는 정적 유체 하중(Hydrostatic force), $F_{D}$ 는 동적 유체 하중(Hydrodynamic force), $F_{M}$ 는 계류선에 의한 장력(Mooring line force)을 의미한다. $F_{M}$ 은 현수선 계류를 적용 하였으며 계류선에 작용하는 관성력과 항력에 의한 효과는 고 려하지 않았다.

\section{3 부유체와 계류 시스템의 연성알고리즘}

Fig. 1에서는 입사파, 부유체, 계류 시스템 간의 상관관계에 따른 모식도를 나타낸다. 입사파는 선형규칙파이고, 파랑으로 야기된 부유체의 표류운동으로부터 위치제어를 위해 현수선형 태의 계류 시스템을 적용하였다. 즉, 시간 영역에서 파랑 중 부 유체의 거동에 대하여 페어리드(Fairlead) 좌표가 현수선 계류 시스템 라이브러리(Library)의 입력값이 되고 부유체의 표류운 동 제어를 위한 계류선의 장력이 현수선 계류 시스템 라이브러 리의 출력값이 되는 알고리즘이다.

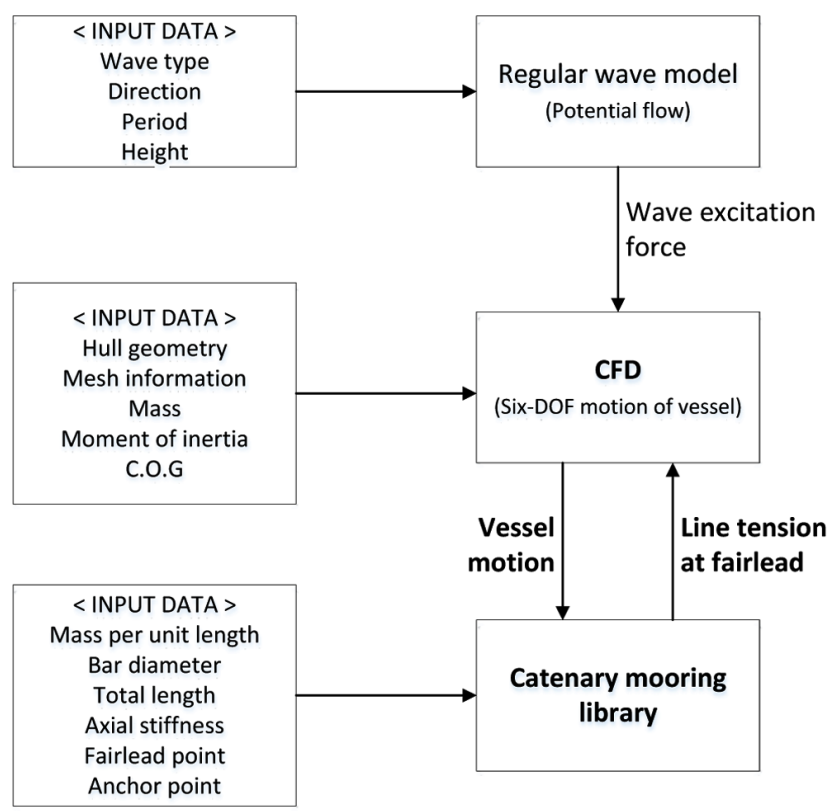

Fig. 1 Coupled analysis diagram 


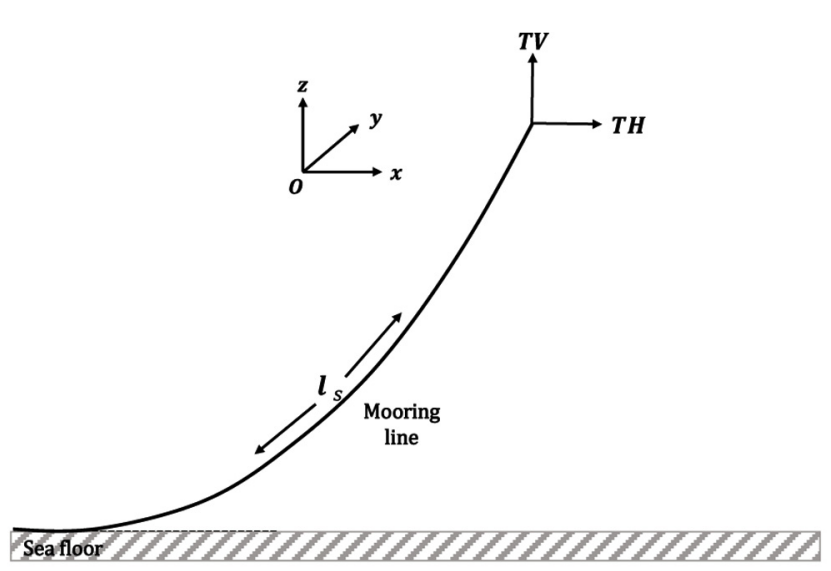

Fig. 2 Catenary shape

Fig. 2는 적용된 현수선 방정식의 형상을 나타내며, 식(10), (11)과 같이 정의된다.

$$
\begin{aligned}
& x\left(l_{s}\right)=\frac{T H}{w}\left[\sinh ^{-1}\left(\frac{T V+w \cdot l_{s}}{T H}\right)-\sinh ^{-1}\left(\frac{T V}{T H}\right)\right] \\
& +\frac{T H \cdot l_{s}}{K} \\
& z\left(l_{s}\right)=\frac{T H}{w}\left\{\sqrt{1+\left(\frac{T V+w \cdot l_{s}}{T H}\right)^{2}}-\sqrt{1+\left(\frac{T V}{T H}\right)^{2}}\right\} \\
& +\frac{T V \cdot l_{s}}{K}+\frac{w \cdot l_{s}^{2}}{2 K}
\end{aligned}
$$

여기서 $l_{s}$ 는 Suspend length, $x\left(l_{s}\right), z\left(l_{s}\right)$ 는 해저면까지의 계류선 길이(Suspend length)에 해당하는 노드(Node)의 $x$ 방향과 $z$ 방향 의 변위, $T H$ 와 $T V$ 는 수평, 수직 방향의 장력, $w$ 는 계류선의 단 위 길이 당 무게, $K$ 는 계류선의 축방향 강성을 의미한다. 매 시 간 간격 마다 계류선의 해저면 접촉지점(Touchdown point)과 Suspend length를 계산하고, 이로부터 현수선 방정식을 이용하여 정적 평형상태의 형상과 페어리드에 작용하는 장력을 계산한다. 여기서, $x, z$ 방향의 정적 평형상태의 형상 및 장력을 나타내는 식 (10), (11)을 만족시키기 위해 비선형 수치해석 방법인 Newton-raphson \& Jacobian 방법을 이용하였다. 수치해석을 위 한 과정은 다음과 같이 3 가지 단계를 따른다.

\section{Step. 1}

식 (10), (11)을 각각 $f_{x^{\prime}, z}\left(\alpha_{n}\right)$ 의 함수로 재배열한다. $x^{\prime}$ 은 계 류선의 로컬 평면에서의 수평 방향의 좌표를 의미하며, $z$ 는 수 심 방향의 좌표를 의미한다.

$$
\begin{aligned}
& f_{x}\left(\alpha_{n}\right)=\frac{T H}{w}\left[\sinh ^{-1}\left(\frac{T V+w \cdot l_{s}}{T H}\right)-\sinh ^{-1}\left(\frac{T V}{T H}\right)\right] \\
& +\frac{T H \cdot l_{s}}{K}-x\left(l_{s}\right) \\
& f_{z}\left(\alpha_{n}\right)=\frac{T H}{w}\left\{\sqrt{1+\left(\frac{T V+w \cdot l_{s}}{T H}\right)^{2}}-\sqrt{1+\left(\frac{T V}{T H}\right)^{2}}\right\} \\
& +\frac{T V \cdot l_{s}}{K}+\frac{w \cdot l_{s}^{2}}{2 K}-z\left(l_{s}\right)
\end{aligned}
$$

\section{Step. 2}

Newton raphson \& Jacobian 방법을 이용하여 매 시간 간격 마 다 변화하는 페어리드 좌표로부터 계류선의 장력을 계산하기 위한 수치해석을 수행한다.

$$
\left[\begin{array}{l}
T H_{n+1} \\
T V_{n+1}
\end{array}\right]=\left[\begin{array}{l}
T H_{n} \\
T V_{n}
\end{array}\right]-\left[\begin{array}{ll}
\frac{\partial f_{1}}{\partial(T H)} & \frac{\partial f_{1}}{\partial(T V)} \\
\frac{\partial f_{2}}{\partial(T H)} & \frac{\partial f_{2}}{\partial(T V)}
\end{array}\right]^{-1} \cdot f\left(\left[\begin{array}{c}
\delta_{T H_{n}} \\
\delta_{T V_{n}}
\end{array}\right)\right)
$$

단, 매 타임스텝마다 장력계산을 위한 반복계산의 범위는 $f_{x, z}\left(\alpha_{n}\right)=\left[\begin{array}{l}\delta_{T H_{n}} \\ \delta_{T V_{n}}\end{array}\right] \leq 10 e^{-7}$ 이다.

\section{Step. 3}

좌표변환 단계이다. 앞서 계산된 $T H, T V$ 는 페어리드와 앵커 링 지점이 이루는 로컬좌표계에서의 수평, 수직 방향의 장력을 의미한다. Fig. 3 은 $z$ 방향을 수심 방향 기준으로 계류선의 $x-y$ 평

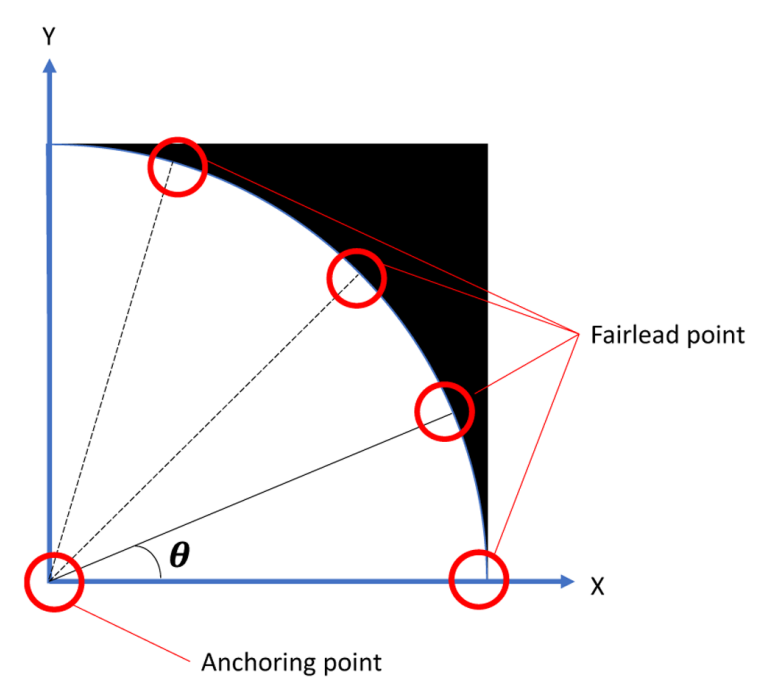

Fig. 3 Fairlead \& Anchoring point in local plane

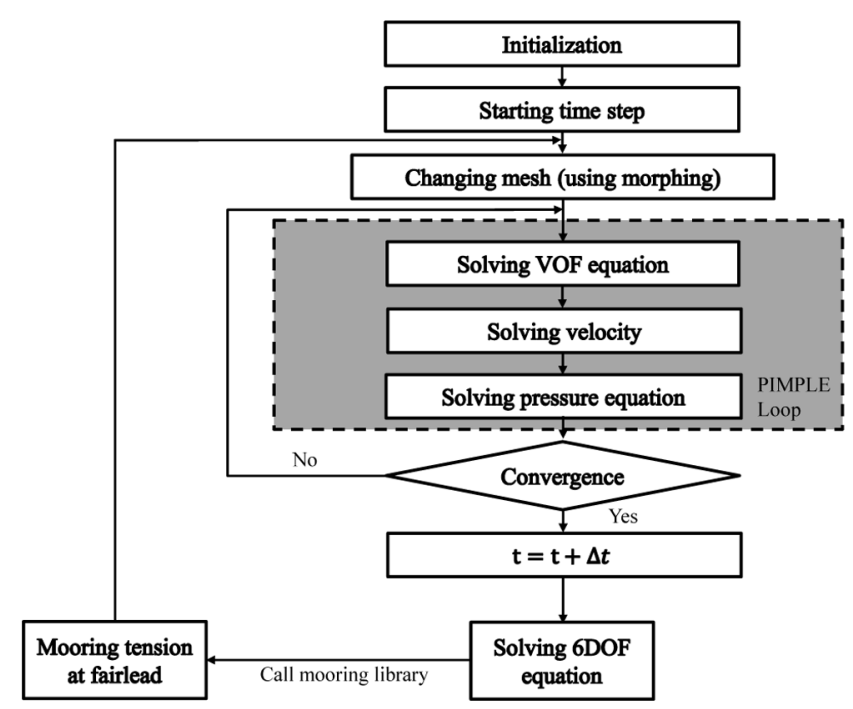

Fig. 4 Flowchart of solving algorithm 
면을 나타내는데, 앵커링 지점이 고정된 환경에서 일직선상 거 리가 동일한 원주에서의 페어리드 장력은 같다는 원리를 통해 전역좌표계로 좌표변환을 수행하였다.

\section{4 해석알고리즘}

유체의 VOF 이송 방정식과 지배방정식은 유한 체적법(Finite Volume Method)에 의하여 이산화 된다. 지배방정식 중 시간 항 은 1차 정확도의 Euler scheme, 공간 항은 2차 정확도의 Linear upwind scheme을 사용하였다. 속도와 압력의 연성을 위해서 SIMPLE 알고리즘과 PISO 알고리즘을 결합한 PIMPLE 알고리 즘을 사용하였다. 수치해석 과정은 Fig. 4와 같다.

\section{5 파랑조건의 정의}

해석 도메인은 $25 \mathrm{~m}(\mathrm{~L}) \times 1 \mathrm{~m}(\mathrm{~B}) \times 1 \mathrm{~m}(\mathrm{D})$ 로 모델링 하였다. 파 랑의 수치 오차를 고려하여 대상 부유체는 조파가 시작되는 경 계면으로부터 한 파장 떨어진 곳에 위치하며 유동장의 앞, 뒤, 양옆의 경계면에 파의 감쇠 영역을 설정하여 벽면효과를 최소 화하도록 설정하였다. 입사파 조건은 개발된 프로그램의 비교 및 검증을 위해 비선형성을 최소화하고자 하였으며, 이에 따라 입사파의 파경사각을 $3^{\circ}$ 미만으로 선정하였다. 입사파는 진폭, 방향, 주기는 Table 1 과 같다. 파고는 $2 \mathrm{~cm}$, 파방향은 선수파 방 향이고, 주기는 1.0 초부터 2.0 초까지 0.2 초 간격으로 총 6 가지 조건으로 수치해석을 수행하였다.

Table 1. Regular wave condition

\begin{tabular}{ccc}
\hline \hline Wave amplitude [cm] & Direction [deg] & Wave period [s] \\
\hline \multirow{2}{*}{1.0} & \multirow{2}{*}{0.0} & $1.0,1.2,1.4$, \\
& & $1.6,1.8,2.0$ \\
\hline
\end{tabular}

\section{6 격자민감도 해석}

파랑에 의한 부유체 운동응답의 해석에 앞서 규칙파에 대한 격자 민감도 테스트를 수행하였다. Fig. 5는 주기가 $1.0 s$ 인 파에 대해 자유수면을 기준으로 입사 파고의 2 배 영역 내에서 $z$ 방향 격자 개수에 따른 파 진폭의 크기 비교를 나타내고 있다. 격자 개수에 따른 파 진폭의 수치오차 비교를 위해 Transient 구간을

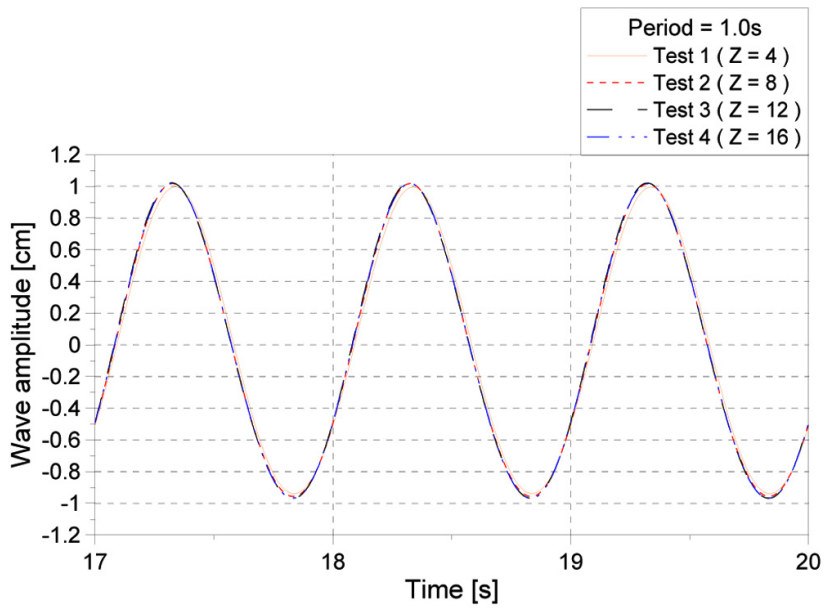

Fig. 5 Comparison of wave amplitude

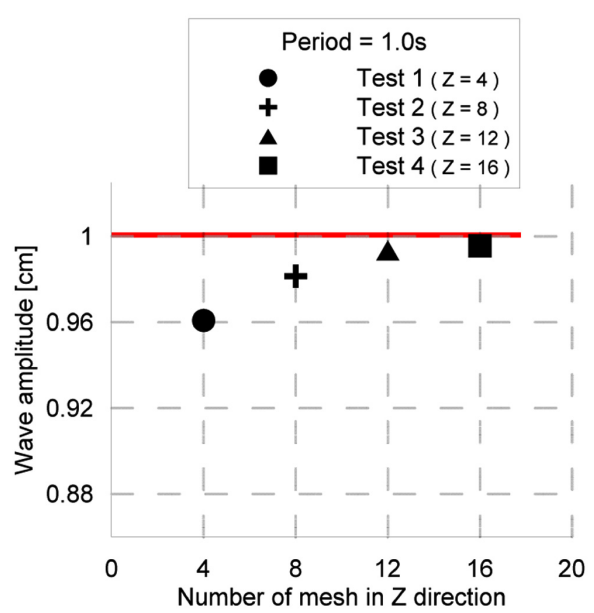

Fig. 6 Mesh sensitivity test

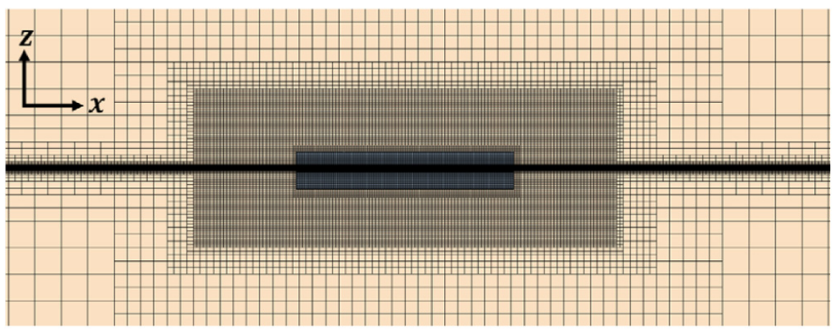

Fig. 7 Grid system

배제하고 Steady 구간에서 3주기의 파 진폭의 평균값을 Fig. 6에 나타내었다. Fig. 6 의 $x$ 축은 파 진폭 방향으로의 격자 개수를 의 미하고, $y$ 축은 계측된 파 진폭을 의미한다.

Fig. 6으로부터 입력한 파 진폭과 계산된 파 진폭을 비교한 결 과, 격자 크기가 가장 큰 Test 1 에서는 약 $4 \%$ 의 오차가 발생하였 고, 격자 크기가 가장 작은 Test 4 에서는 약 $0.5 \%$ 오차가 발생하였 다. 계산 정도와 계산시간의 합리적인 절충안으로써 약 $0.7 \%$ 의 오차를 보이는 Test3 격자 크기를 선정하여 수치해석을 수행하 였다. Fig. 7은 유동장의 격자분포를 나타낸다. 자유수면의 정도 높은 계산을 위해 파가 지나가는 영역에 가장 조밀한 격자를 생 성하였으며 앞서 수행한 격자 수렴도 테스트를 바탕으로 한 파 장을 기준으로 $x$ 방향 약 130 개, $z$ 방향 12 개의 격자를 적용하였다. 또한, 부유체의 운동 응답의 정도를 높이기 위해 부유체 주위에 격자 조밀도를 증가시켰다. 시간영역 계산을 위한 시간간격은 $\mathrm{T}$ (주기)/200s이고, 총 사용된 격자의 수는 $1,300,000$ 개이다.

\section{3. 포텐셜 기반의 연성해석}

\section{1 부유체 운동}

부유체의 운동은 경계요소법(Boundary Element Method, BEM) 을 이용하는 ANSYS AQWA를 사용하여 계산하였다. 이상유체 를 가정한 선형 포텐셜 이론을 기반으로 단위진폭을 가지는 선 형파에 대한 부유체의 운동 응답 및 파랑 하중을 계산 하였다. 주파수 영역에서 부가질량계수(Added mass coefficient), 방사감 쇠계수(Radiation damping coefficient), 파진기력(Wave exciting force) 등을 산출하고 이를 통해 입사파의 주파수에 대한 운동의 
크기를 나타내는 진폭 응답 함수(Motion RAO)를 계산하였다.

\section{2 부유체와 계류시스템간의 연성해석}

유한요소법(Finite Element Method, FEM)을 이용하는 상용프 로그램인 Orcaflex를 통하여 부유체와 계류 시스템 간의 시간 영역 연성해석을 수행하였다. Orcaflex를 통한 수치해석은 전체 계류선의 세그먼트에 따라 노드점과 스프링의 개수가 정해지고, 이를 통해, 각 노드점에 질량을 부과하는 집중질량법(Lumped mass)을 기반으로 한다. Fig. 8 과 같이 총 4 개의 계류선이 선수 선미로부터 좌현, 우현으로 향하도록 계류선을 배치하였고 페 어리드와 앵커링 지점의 수평 방향 거리와 수심의 비를 의미하 는 계류선반경(Foot print radius)은 2배로 설계하였다.

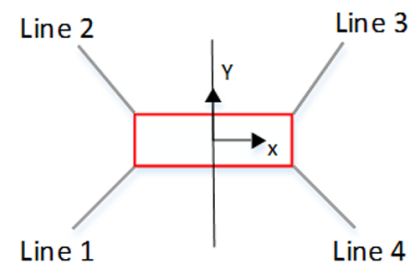

Fig. 8 Layout of mooring lines

또한, 계류선의 양력 및 항력계수는 각각 $2.4,1.5$ 로 계산하였 다. 이는 DNVGL-OS-E301(2015)에서 제공하는 값을 기준으로 산정하였다.

\section{4. 결과 비교}

\section{1 정적평형과 초기장력}

파랑 하중을 적용하기에 앞서 정적 평형상태(Static equilibrium state)에서 계류선의 형상 및 페어리드에 작용하는 장력을 비교하 였다. Fig. 9는 페어리드에서 앵커링 지점까지 총 50 개의 세그먼 트로 나눈 계류선의 형상을 나타내고 있다. 개발된 OpenFOAM과 상용프로그램인 Orcaflex 간의 전체적인 형상이 잘 일치함을 확 인할 수 있다.

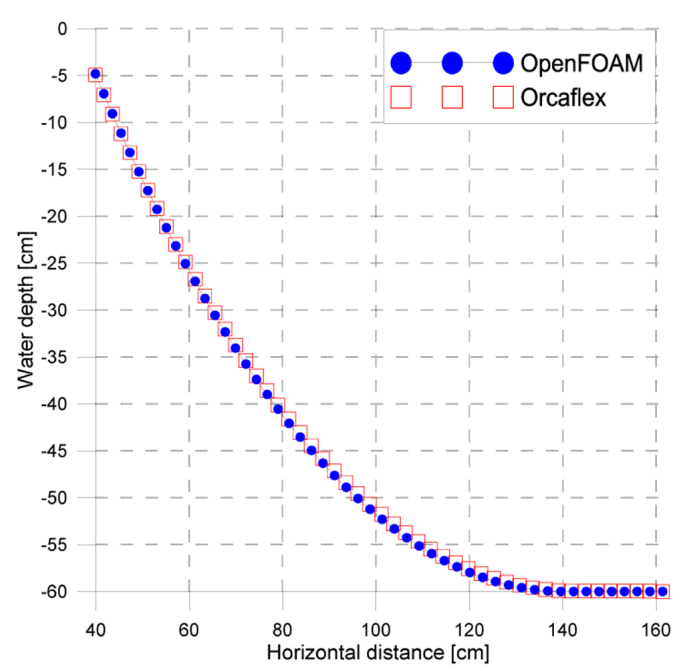

Fig. 9 Equilibrium profile

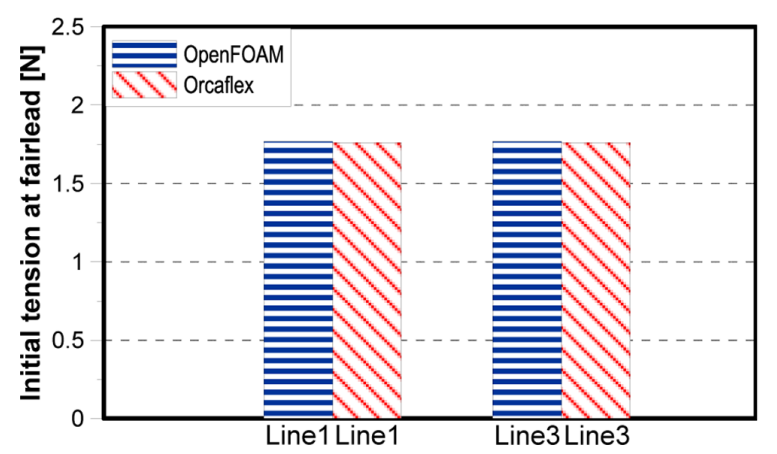

Fig. 10 Initial tension at fairlead

Fig. 10은 페어리드에 작용하는 계류선의 초기장력을 비교한 그림이다. Line1, Line3은 선수, 선미의 대각선 방향에 위치한 계류선을 나타낸다. 현수선 방정식으로부터 계산된 OpenFOAM 계류 시스템의 초기장력은 Orcaflex의 결과와 잘 일치하는 것을 확인할 수 있다.

\section{2 부유체의 거동과 계류장력}

입사파의 각도가 $0^{\circ}$ (선수파)인 조건에서 입사파 주기에 따른 부유체 운동 응답 특성 및 계류선의 장력변화에 대한 비교를 수행하였다(Davidson and Ringwood, 2017).

Fig. 11은 주기가 1.6s인 조건에서 OpenFOAM, Orcaflex로부터
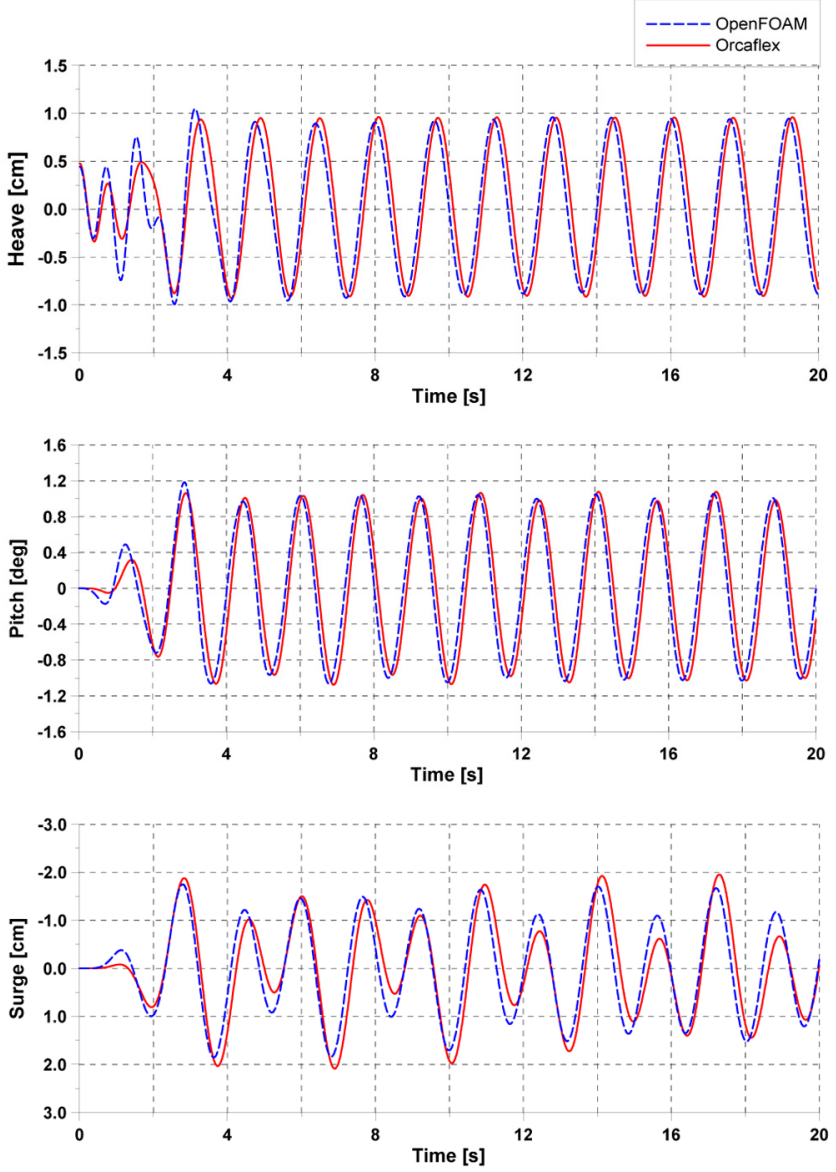

Fig. 11 Time history of motion response $($ period $=1.6 \mathrm{~s})$ 

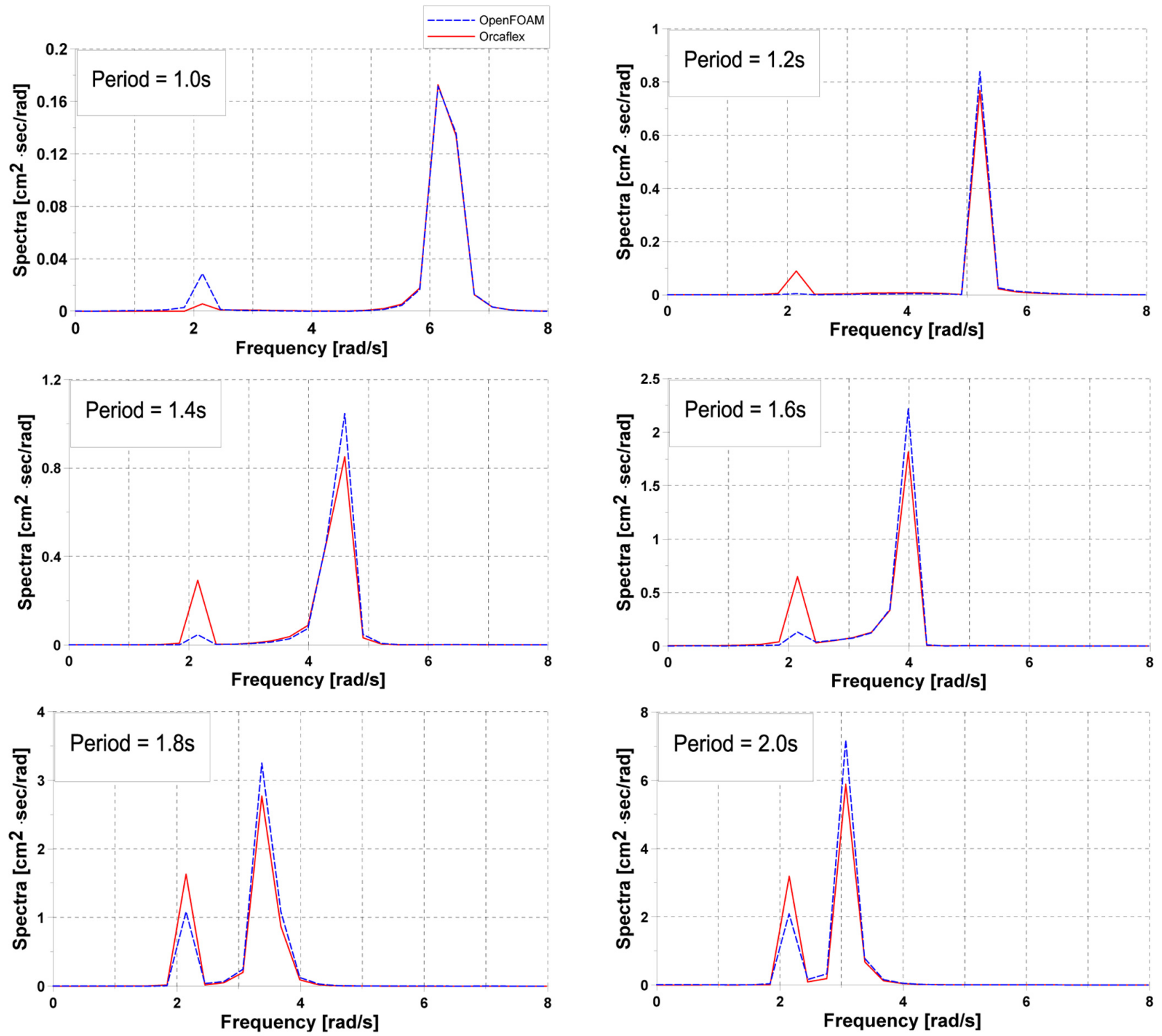

Fig. 12 Surge response spectrum
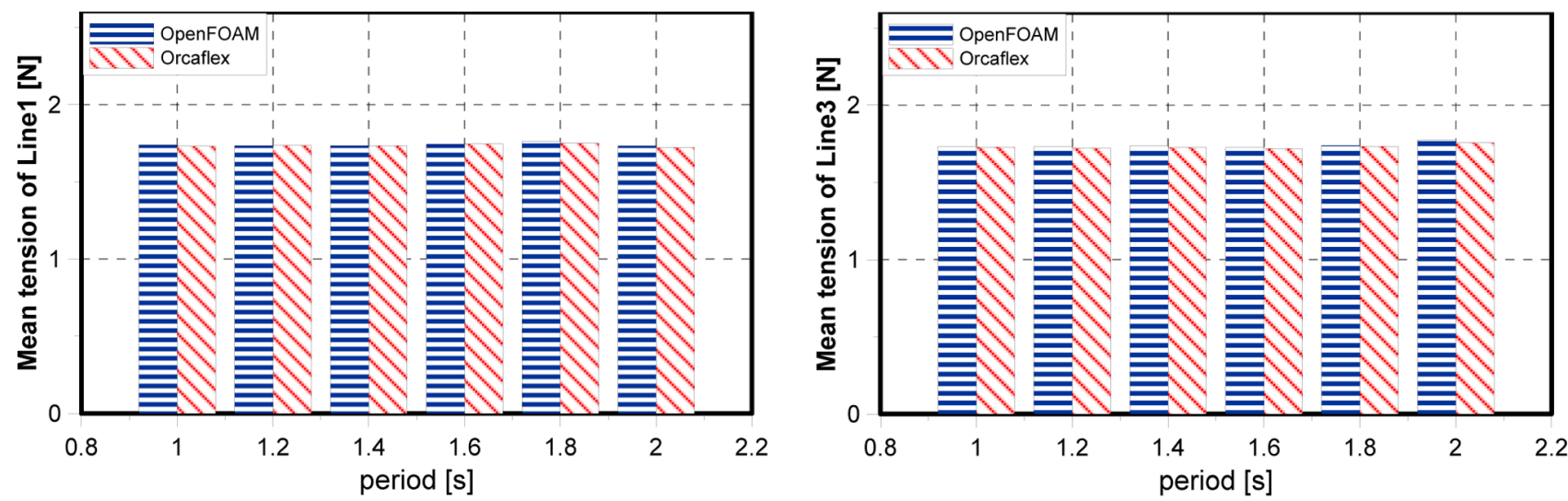

Fig. 13 Mean tension at fairlead

계산된 부유체의 운동 응답에 대한 시계열을 나타낸다. 정량적 비교를 위해 두 수치해석 간의 위상(Phase)을 맞추어 비교하였 다. Heave와 Pitch의 경우 두 개의 시그널이 정량적으로 잘 일치
하는 것을 확인할 수 있다. Surge 응답에서는 정량적으로 일부 상이한 결과가 나타나지만, 개발된 계류모듈 코드는 Orcaflex의 결과와 정량적으로 유사한 결과를 보여주는 것을 확인하였다. 


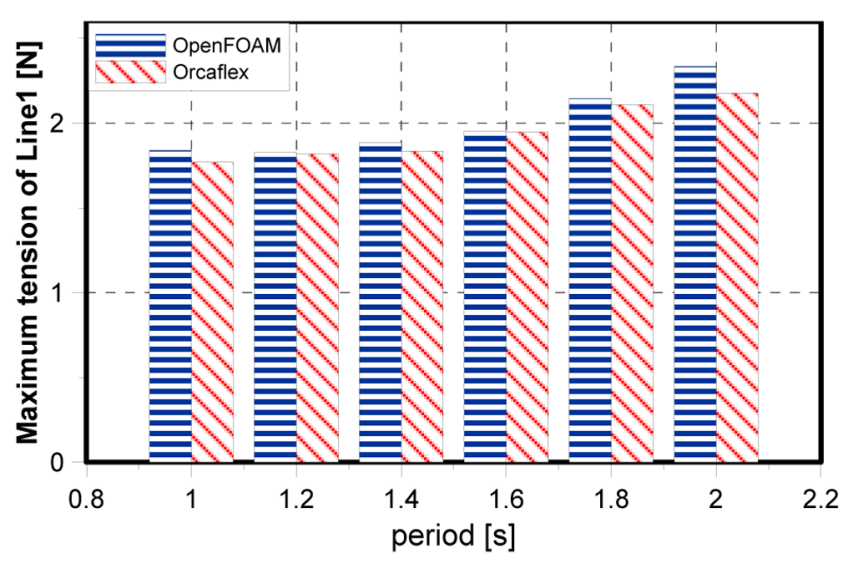

Fig. 14 Maximum tension at fairlead

또한, Surge 응답에서 부유체와 계류시스템 간의 연성 운동으로 부터 기인하는 하모닉(Harmonic) 현상이 관측되고 있는데, 이를 해석하고자 각각의 시간이력을 파워스펙트럼으로 Fig. 12에 나 타내었다.

Fig. 12는 입사파의 주기에 따른 Surge 운동의 파워스펙트럼 을 나타낸다. 스펙트럼마다 2개의 피크가 확연히 구분되어 관찰 되는데 상대적으로 고주파수에 위치한 피크는 입사파의 주파수 를 의미하고 저주파수인 $2.2 \mathrm{rad} / \mathrm{s}$ 에 위치하는 피크는 계류시스템 의 고유진동수와 일치하는 응답을 의미한다. OpenFOAM과 Orcaflex의 결과들 간에 진폭의 차이는 존재하지만 각각의 파 주파수와 계류시스템의 고유진동수에 의한 피크위치는 정확히 예상하는 결과와 일치하는 것을 확인 할 수 있다.

Fig. 13,14 는 계류선의 장력에 대해 평균값과 최대값을 나타 내었다. 장력의 평균값은 두 방법 간에 큰 차이를 보이지 않았 으나 장력의 최대값은 특정 파주기에서 약간의 차이를 보이고 있는데, 이는 개발된 계류시스템용 모듈이 현수선방정식을 사 용함으로써 평면내의 운동만 표현이 가능하고, 동역학적인 계 류선의 거동을 표현하는데 한계가 있어서 생기는 것으로 판단 된다. 이는 추후 모형실험을 통해 추가적인 비교를 수행하거나, 연성모듈의 현수선방정식을 집중질량법으로 개량하는 방법을 통해 검증이 이루어질 예정이다.

\section{5. 결 론}

본 연구에서는 오픈소스 CFD 프로그램인 OpenFOAM를 이용 하여 부유체와 계류 시스템간의 양방향 연성 모듈을 개발하고 이를 상용프로그램의 수치해석결과와 비교하여 검증하였다. 정 적평형 상태에서 계류선의 형상 및 초기장력을 비교했으며, 선 수파 조건의 규칙파 조건에서 부유체의 거동 및 페어리드 지점 의 장력을 주파수 영역에서의 스펙트럼 및 시간영역에서의 최 대값과 평균값을 통해 정량적으로 평가하였다. 본 연구로부터 다음과 같은 결론을 얻을 수 있다.

(1) 개발된 OpenFOAM 코드의 Heave, Pitch 운동은 상용프로 그램인 Orcaflex간에 정량적으로 잘 일치하는 것을 확인하였다.

(2) 개발된 OpenFOAM 코드의 Surge 운동 및 계류선의 장력 은 상용프로그램인 Orcaflex와 정량적으로 허용 범위 내의 차이

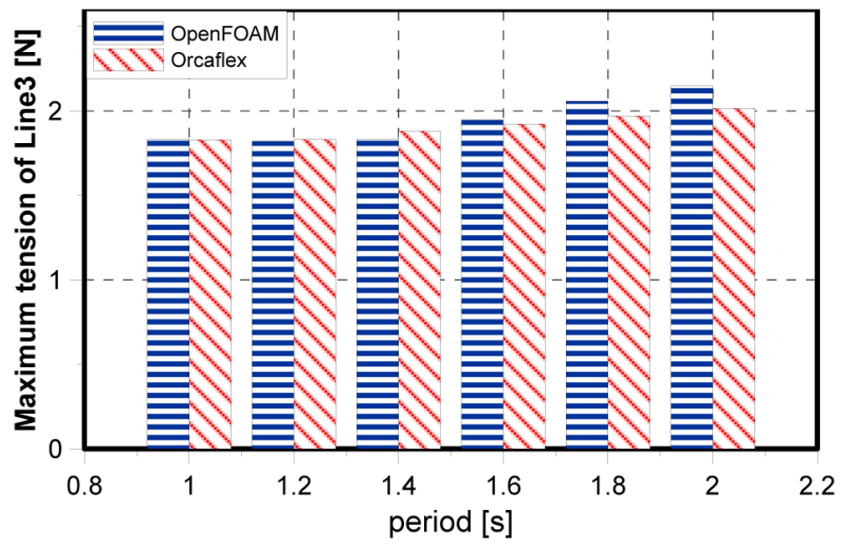

를 보이며 같은 경향을 보임을 확인하였다.

(3) 본 논문에서는 점성효과를 고려하는 $\mathrm{CFD}$ 를 이용하여 부 유체와 계류 시스템간의 연성 운동을 구현하였다. 추후 모형 실험 또는 연성모듈의 개선을 통해 추가적인 비교 및 검증이 필요하며, 더 나아가 이를 바탕으로 극한 환경 조건과 계류선의 동적 효과를 고려한 연구가 요구된다.

$$
\text { 후기 }
$$

본 연구는 산업통산자원부 산업기술혁신사업 (과제번호: 10063405) “위치유지와 계류 시스템을 적용하여 ARC7 조건에서 연중운용이 가능한 북극해 기반 부유식 해양구조물 형상 개발”과제의 지원으 로 수행되었음을 밝힙니다.

\section{References}

Davidson, J., Ringwood, J. V., 2017. Mathematical Modelling of Mooring Systems for Wave Energy Converters-A Review. Energies, 10(5), 666.

DNVGL, 2015. Position Mooring. DNVGL-OS-E301, DNV GL AS.

Hong, S.Y., Lee, P.M., Kim, Y.C., Hong, D.C., 1988. An Experimental Analysis on the Motion Response of a Moored Semi-Submersible Platform in Regular Waves, Journal of Ocean Engineering and Technology, 2(1), 59-70.

Ok, H. T., Lee, S. J., Choi, J. H., 2017. Numerical simulation of motion of single and side-by-side vessels in regular waves using OpenFOAM. Ships and Offshore Structures, 12(6), 793-803.

Sirnivas, S., Yu, Y. H., Hall, M., Bosma, B., 2016. Coupled mooring analyses for the wec-sim wave energy converter design tool. In ASME 2016 35th International Conference on Ocean, Offshore and Arctic Engineering (pp. V006T09A023-V006T09A023). American Society of Mechanical Engineers.

Wu, G., Kim, J. W., Jang, H., Baquet, A., 2016. CFD-Based Numerical Wave Basin for Global Performance Analysis. OMAE2016. 